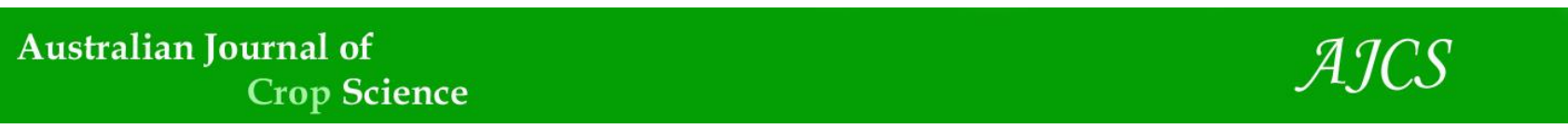

AJCS 15(03):348-353 (2021)

ISSN:1835-2707

doi: 10.21475/ajcs.21.15.03.p2705

\title{
Morphophysiology of Jatropha curcas L. plants under different water regimes
}

\author{
Thiago Souza Campos ${ }^{1}$, Westefann dos Santos Sousa ${ }^{1}$, Alan Abadio da Silva ${ }^{1}$, Valdivino Domingos de \\ Oliveira Júnior ${ }^{1}$, Walter Pires Júnior ${ }^{1}$, Thaís Fernandes de Jesus ${ }^{1}$, Larissa Pacheco Borges ${ }^{2}$, Fábio Santos \\ Matos $^{3}$
}

\author{
${ }^{1}$ Plant Production of UEG, Ipameri University Unit, Brazil \\ ${ }^{2}$ State University of Goiás (UEG), Ipameri University Unit, Brazil \\ ${ }^{3}$ Graduate Program in Plant Production of UEG, Ipameri University Unit, GO 330, Km 241, ring road, university \\ sector, 75780-000-Ipameri, Brazil
}

*Corresponding author: fabio.agronomia@hotmail.com

\begin{abstract}
The effect of different water regimes on Jatropha curcas seedling growth was investigated. The study was carried out in a greenhouse covered with transparent plastic. Seeds were sown in five-liter recipients containing substrate consisting of 3:1:0.5 soil, sand and manure, respectively. A completely randomized plot design was used with seven treatments and five replications. The plants were irrigated with $100 \%$ substrate retention capacity until 30 days of age when they were submitted to water volumes of $25 \%, 50 \%, 75 \%, 100 \%, 125 \%, 150 \%$ and $175 \%$ substrate retention capacity for 30 days. The short duration of the research explains the slight decreases in the RMR and TRA but they were sufficient to support the assertion that excess water may have inhibited aquaporin activity and partially reduced soil solution absorption and TRA. Thus, both water deficit and excess water inhibited the growth of $J$. curcas plants, however, the water deficit inhibited more strongly the development of the species at the initial stages of the restriction, while excess water only caused damage after a longer period of exposure. The assessments were made when the plants were 60 days old. The J. curcas plants showed an isohydric mechanism of stomatal control and maintained turgidity under water shortage, and, under excess water, the alterations in the root system and relative water content preceded reduction in stomatal conductance. The initial growth of $J$. curcas plants was shown to be sensitive to water shortage and but not very vulnerable to water excess.
\end{abstract}

Keywords: biofuel; development; drought; flooding; oxygen deficiency.

Abbreviations: Car_carotenoids; $\mathrm{Cl}$ a_chlorophyll a; $\mathrm{Cl} b$ _chlorophyll b; DAE_days after emergence; DMSO_dimethyl sulfoxide; $E_{-}$

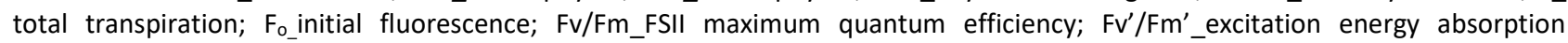
efficiency by the open FSII reaction centers; J. curcas_Jatropha curcas; LMR_ leaf mass ratio; LN_ leaf number; NPQ_Nonphotochemical energy dissipation; $\mathrm{PH}_{-}$plant height; $\mathrm{qP}$ _photochemical dissipation; RMC_stem matter ratio; RMR_stem matter root; SD_stem diameter; TRA_relative water content

\section{Introduction}

The $J$. curcas species is a fast-growing, deciduous perennial bush, belonging to the family Euphorbiaceae and can reach a height of five meters (Abobatta, 2019). The plant has many uses, important pharmacological properties with hemostatic healing effect (burns) and is antifungal (Matos, 2018). The seeds have a high oil content ( 30 to $45 \%$ ) easily converted to biodiesel so that this perennial bush has large economic potential (Kamel et al., 2018).

The high oil content in J. curcas seeds and low production costs have triggered much interest at national and international levels. In Brazil, it is estimated that 50.000 hectares are planted with this crop, of which 30 thousand hectares are on mid- and large-sized properties and the rest are cropped by family agriculture (Durães et al., 2009). The $J$. curcas species can be grown in various regions of Brazil because it is robust and resistant to long periods of drought making it adaptable to different edaphoclimatic conditions (Silva et al., 2018). However, production is concentrated in semi-arid regions, and it is an alternative bioenergetic crop that is more resistant to abiotic stresses than sugarcane (Souza et al., 2016).

The increase in the cropped area has created large demands for information, mainly on crop management, but studies have shown wide variations in yield. Drumond et al. (2016) assessed the performance of $J$. curcas genotypes under irrigated conditions in the arid Brazilian northeast and reported yields ranging from 2.85 to $3.54 \mathrm{t} \mathrm{ha}^{-1}$, while Matos et al. (2014a), in the region of Ipameri-GO, Central Western Brazil, indicated average J. curcas yields of around $37.6 \mathrm{~kg}$ $\mathrm{ha}^{-1}$ when cropped alone and $30.2 \mathrm{~kg}^{-1}$ when intercropped with soybean.

Brazil has wide climatic diversity, but most cropping regions are subject to irregular or excessive rainfall or drought conditions during meteorological phenomena such as El Niño and La Niña (Cunha et al., 2018). Under extreme environmental conditions, such as water shortage or 
inundation flooding, plants need to use anatomic and morphophysiological mechanisms to minimize the adverse effects, such as stomatal closure, decrease in leaf area and leaf senescence (Gomes et al., 2018). There is also investment in growth and lenticel hypertrophy and damage to photosystem II (due to the activation of anaerobic routes) characteristics of inundation (Tavares et al., 2018). These factors interfere directly in plant growth, reflecting on the yield of the crops of interest, because energy is deviated from the primary metabolism to overcome damage from adverse environments.

J. curcas plants are able to tolerate drought because they have mechanisms that decrease dehydration and reduce the leaf transpiration rate that maintain the tissues hydrated (Matos et al. 2018). Under inundated soil conditions, the plant tends to decease its leaf area, reducing the photosynthesis rate and stomatal conductance, due to the restriction in gas exchanges from stomatal closure (Padilha et al., 2016).

Bearing in mind the economic importance of $J$. curcas for the renewable energy production scenario, as well as a greater understanding of basic agronomic aspects regarding the performance of $J$. curcas under abiotic stresses, the current study proposes to identify the performance of the species in opposite of water supply ranges (excess and deficit) and, therefore, understand part of the limitations to J. curcas cultivation. The present study aimed to identify the effect of different water regimes on J. curcas seedling growth.

\section{Results and discussion}

The variables chlorophyll and total carotenoids, FSII maximum quantum efficiency (Fv/Fm) and excitation energy absorption efficiency by the open FSII reaction centers $\left(\mathrm{Fv}^{\prime} / \mathrm{Fm}^{\prime}\right)$ were not significantly different in the various water regimes $(P<0.05)$ and did not fit any regression model.

The analysis of variance showed significant effect $(P \leq$ 0.05 ) among the water regimens studied. The variables in Figure 1 show that there was linear growth in plant height with a $43 \%$ increase in the maximum water regime used (175\%) compared to the lowest water regime of $25 \%$ substrate retention capacity (Figure 1A). The stem diameter showed linear growth until the $50 \%$ water regime and remained stable with increase in water availability (Figure 1B).

The number of leaves increased linearly and was directly proportional to the increase in water supply (Figure 1C). The maximum water availability resulted in a $68.5 \%$ increase in the number of leaves compared to the lowest water regime. The transpiration rate presented values directly proportional to water availability with a $195 \%$ increase in transpiration in the highest water regime compared to the minimum amount of water supplied in the experiment (Figure 1D). The results for relative water content (TRA) showed a quadratic increase in relation to water availability in the soil with maximum TRA of $67 \%$ in the water regime with $132 \%$ substrate retention capacity (Figure 1E).

The root matter data presented quadratic fit with the maximum point of 0.16 under $140 \%$ water regime (Figure $2 \mathrm{~A})$. The variable stem matter ratio (Figure 2B) showed linear decrease as the water regimes increased while the leaf matter ratio presented linear increase proportional to the increase in water availability (Figure $2 \mathrm{C}$ ).
The initial fluorescence $\left(F_{0}\right)$ fitted a quadratic regression with maximum point in the $25 \%$ water regime and 224 initial fluorescence, while in the water regime representing inundation $(175 \%)$, the initial fluorescence was 159.80 (Figure 2D). Comparison of the extreme water regimes showed that photochemical dissipation (qP) decreased linearly by $5.8 \%$ (Figure 2E). Non-photochemical energy dissipation (NPQ) had quadratic fit, decreasing up to the $125 \%$ regime and increasing again as the 150 and $175 \%$ water volumes were applied (Figure 2F).

Multiple regression analysis showed that the following variables contributed positively to the total J. curcas biomatter: plant height, stem diameter and transpiration but leaf matter ratio contributed negatively to the total biomass (Table 1 ).

Although the pharmacological potential of the latex and the quality of the oil from J. curcas are known, scientific information is still lacking on the species (Matos et al., 2018). Little is known about the J. curcas biochemistry and physiology, there are no defined cultivars and some agronomic aspects have not been investigated, such as tolerance to drought, inundation or cold, leaf longevity and factors that trigger leaf senescence (Almeida et al., 2019), so further studies are being developed to elucidate these aspects. The results in the present study indicated striking physiological differences regarding stomatal sensitivity in $J$. curcas plants under water shortage and irrigation, as is discussed next.

The growth of $J$. curcas plants was shown to be highly dependent on water availability. The shoot showed exuberant growth in height, diameter, number of leaves and leaf matter ratio. The start and development of the first leaf depend on the water status of the plant, so that all the variables related to the leaves showed linear increase due to increase in water availability.

Water shortage damages the leaf metabolism, growth and initiation. Larger water availability increased the stem diameter and may have increased the water conductivity from the roots to the leaves, but it did not increase the stem matter ratio (RMC), possibly due to the greater partition of assimilates for leaf biomass. The data confirmed findings by Matos et al. (2014b) who reported the importance of water in the initial growth of $J$. curcas plants and identified decrease in leaf initiation under water shortage.

Transpiration depends on water availability and transpiration and growth increased as the volume of water applied increased. As $\mathrm{CO}_{2}$ uptake occurs through the same pore as water loss, it can be inferred that the high growth occurred at water status coincident with high transpiration. According to Matos et al. (2014b) J. curcas seedlings are tolerant to water shortage and have a tolerance strategy of delaying dehydration by reducing the transpiration rate.

The high stomatal control typical of isohydric plants affects the carbon assimilation rate and reduces growth under low water availability (Matos et al., 2014b). In the present study, the $J$. curcas plants showed high stomatal sensitivity under water deficit but did not present the same sensitivity under inundation. This result differs from that reported by Padilha et al. (2016) of low stomatal conductance in inundated environments. However, the short exposure time to excess water justified the low stomatal sensitivity and high transpiration in the present study and indicated that there were differences regarding the stomatal conductance in the leaves of J. curcas plants under water shortage and inundation. 
Table 1. Multiple regression model to assess the importance of plant height (PH), leaf mass ratio (LMR), stem diameter (SD), total transpiration $(E)$, photochemical quenching ( $\mathrm{qP}$ ) and leaf number (LN) on total biomas of irrigated Jatropha curcas plants with different water volumes.

\begin{tabular}{|c|c|c|c|c|c|c|}
\hline \multirow[b]{2}{*}{ Biomas } & \multicolumn{2}{|l|}{$R^{2}=0,94$} & \multicolumn{2}{|c|}{$F(06,28)=74,13$} & \multicolumn{2}{|l|}{$p<0,0000$} \\
\hline & Beta & Std.Err. of Beta & $\mathrm{B}$ & Std.Err. of B & $\mathrm{t}(28)$ & $\mathrm{p}$-level \\
\hline Intercept & & & -16.39960 & 8.44102 & -1.94285 & 0.06215 \\
\hline $\mathrm{PH}$ & 0.74290 & 0.09905 & 0.76734 & 0.10230 & 7.50061 & 0.00000 \\
\hline SD & 0.24883 & 0.08812 & 4.26011 & 1.50864 & 2.82381 & 0.00864 \\
\hline$E$ & 0.10958 & 0.05019 & 0.00274 & 0.00125 & 2.18329 & 0.03756 \\
\hline
\end{tabular}
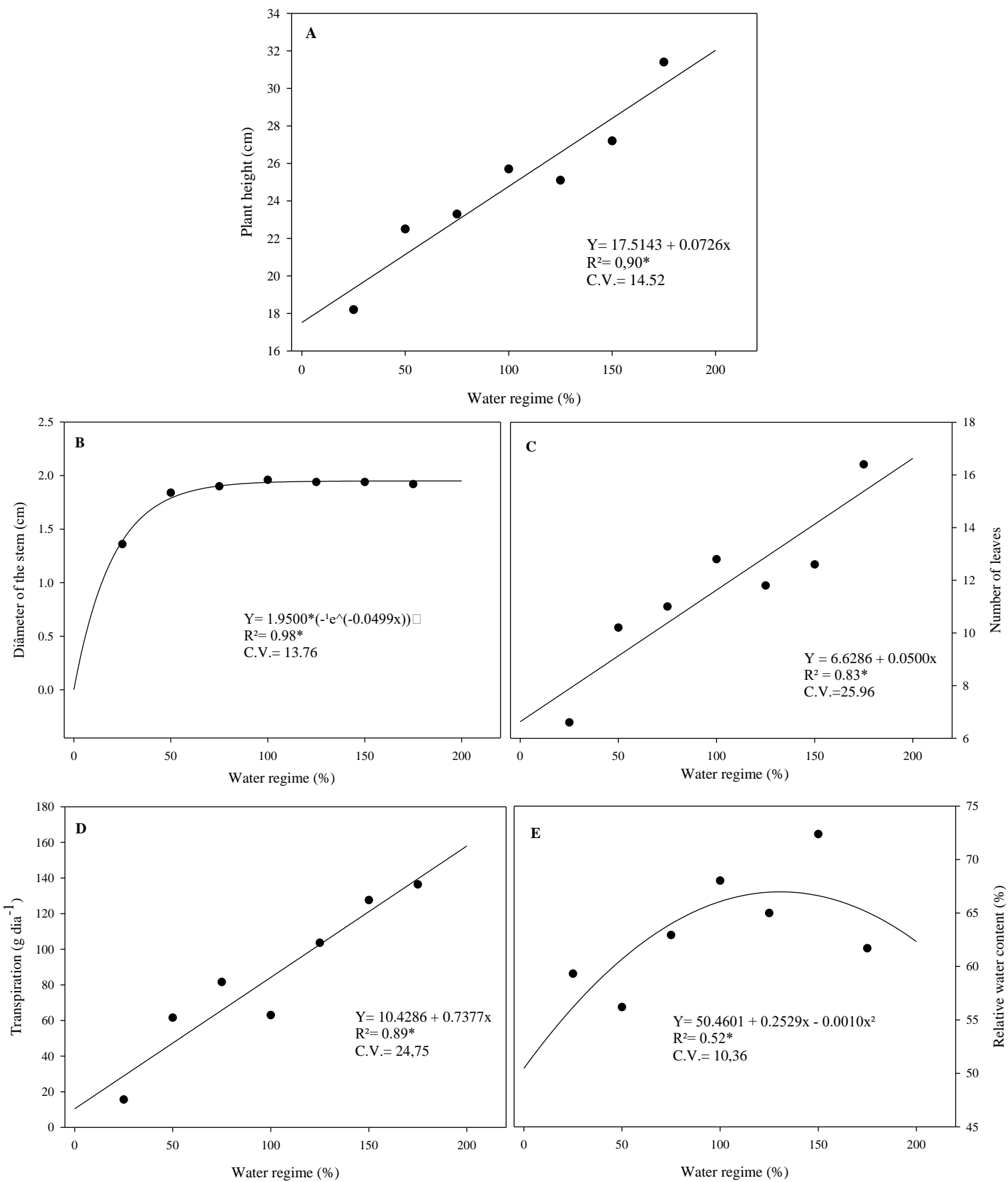

Fig 1. Regression equations for the variables plant height (A), stem diameter (B), number of leaves (C), transpiration (D) and relative water content $(E)$ in Jatropha curcas plants submitted to different water volumes referent to the substrate retention capacity (water regime). *Significant at $5 \%$ error probability by the $\mathrm{F}$ test. 

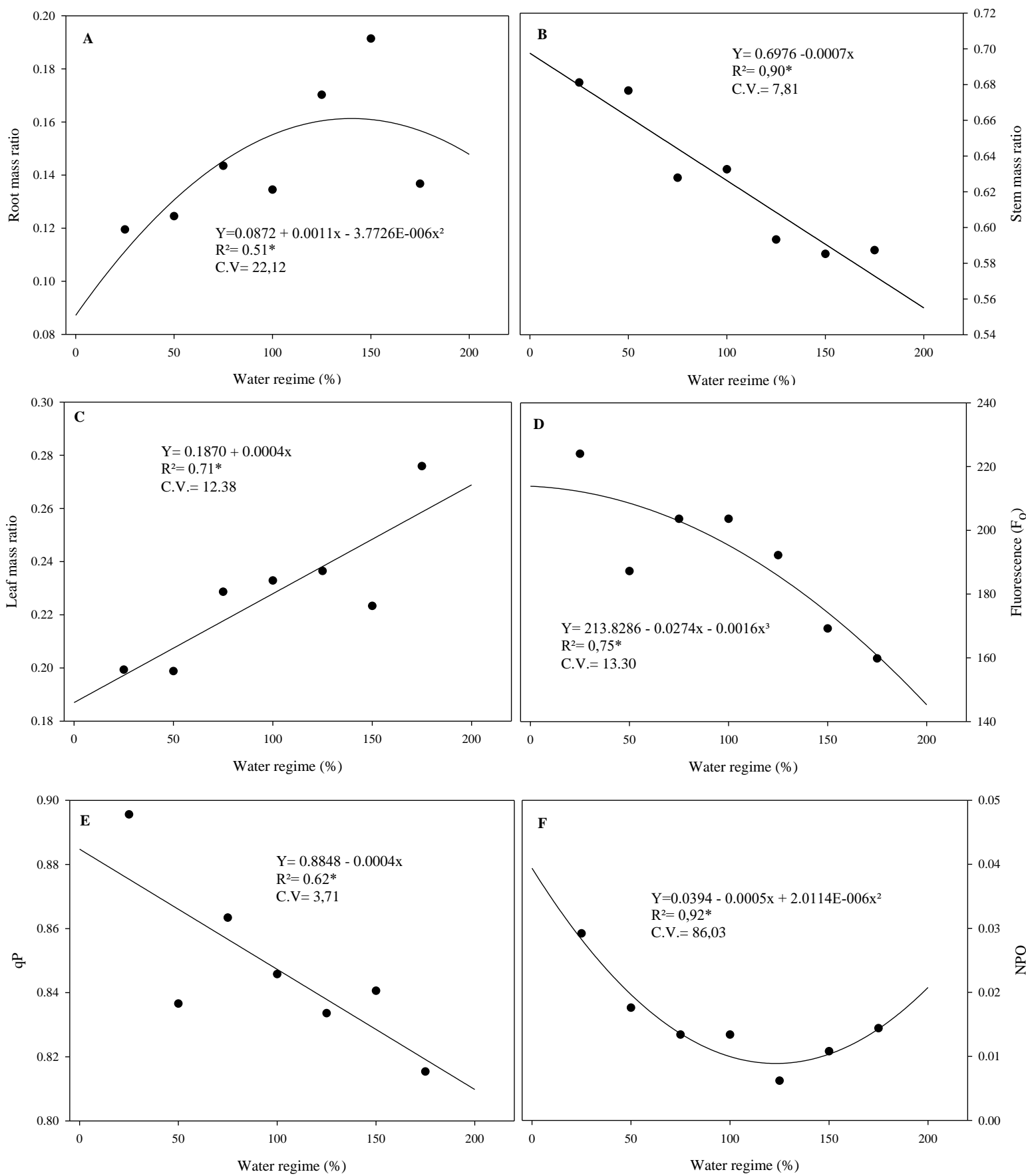

Fig 2. Regression equations for the variables root matter ratio (A), stem matter ratio (B), leaf matter ratio (C), initial fluorescence "Fo" (D), photochemical extinction coefficient "qP" (E) and non-photochemical extinction coefficient "NPQ" (F) in J. curcas plants submitted to different water volumes referent to the substrate retention capacity (water regime). *Significant at $5 \%$ error probability by the $\mathrm{F}$ test.

Although the photochemical extinction coefficient (qP) decreased with increased water availability, the small variation indicated that the photochemistry of photosynthesis was little affected by water shortage or inundation and the decrease in growth under low water availability was related to the diffusive reduction in $\mathrm{CO}_{2}$. However, the reduction in the initial fluorescence and increase in the non-photochemical extinction coefficient (NPQ) starting with water supply at $125 \%$ substrate retention capacity indicated activation of photoprotection mechanisms, as according to Pompelli et al. (2010) the $J$. curcas plant has an efficient photoprotection mechanism.
These slight alterations in Fo and NPQ are the first indication of stress in the shoot caused by excess water.

The decrease in the relative water content starting with water supply at $132 \%$ substrate retention capacity was in line with the reduction in the root matter ratio under excess water. These results together demonstrated that inundation interfered in the root system growth and leaf water status. The roots, in addition to sustaining the plant and absorbing water and mineral nutrients, also function as soil sensors and are certainly the first organ to identify inundation.

The short duration of the research explains the slight decreases in the RMR and TRA but they were sufficient to support the assertion that excess water may have inhibited 
the activity of the aquaporins and partially reduced soil solution absorption and TRA. Thus, both water deficit and excess water inhibit the growth of $J$. curcas plants, but water deficit more strongly inhibits the development of the species at the very initial stages of the restriction, while the excess water only causes damage after a longer period of exposure. Excess water in the soil reduces the spaces for gases and if the situation remains, inhibited cell respiration, reduced cytosol $\mathrm{pH}$ and inhibited aquaporin activity are common, as reported by Taiz et al. (2017).

\section{Materials and Methods}

The study was carried out between March and May 2019 in greenhouse covered with transparent plastic and shade cloth on the sides with $50 \%$ light interception at the State University of Goiás, Ipameri campus (Lat. $17^{\circ} 42^{\prime} 59,12 \mathrm{~S}$, Long. 48 $08^{\prime} 40,49^{\prime \prime}$ West, Alt. $773 \mathrm{~m}$ ), Ipameri, GO, Brazil. The region has a tropical climate with dry winter and wet summer (Aw) according to the Köppen classification and $20^{\circ} \mathrm{C}$ average temperature (Alvares et al., 2013). Three $J$. curcas seeds were sown per $5 \mathrm{~L}$ pot filled with $5 \mathrm{Kg}$ substrate containing oxisol, sand and manure at 3:1:1, respectively. The chemical analysis of the soil showed the following aspects: $\mathrm{pH}\left(\mathrm{CaCl}_{2}\right) 5.4 ; 16 \mathrm{~g} \mathrm{dm}^{-3}$ organic matter; $68 \mathrm{mg} \mathrm{dm}^{-3}$

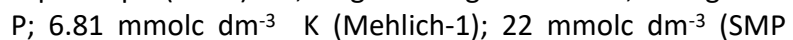
Method) $\mathrm{H}+\mathrm{Al} ; 31 \mathrm{mmolc} \mathrm{dm}^{-3} \mathrm{Ca} ; 15 \mathrm{mmolc} \mathrm{dm}^{-3} \mathrm{Mg} ; 53$ mmolc $\mathrm{dm}^{-3}$ Base Saturation; 75 mmolc $\mathrm{dm}^{-3}$ Cation Exchange Capacity and 71\% Base Saturation.

\section{Treatments}

ifteen days after emergence (DAE) the plants were thinned, leaving one plant in each pot. The experiment was set up in a completely randomized design with seven treatments and five replications. Thirty DAE the plants were irrigated with water volumes according to $25 \%, 50 \%, 75 \%, 100 \%, 125 \%$, $150 \%$ and $175 \%$ substrate holding capacity. The water volume provided daily was - determined according to the holding capacity of the substrate, described by SA et al. (2017).

At 60 DAE the following analyses were carried out: number of leaves, plant height, stem diameter, biomass, root mass ratio, stem mass ratio, leaf mass ratio, photosynthetic pigments, relative water content, transpiration and chlorophyll $a$ fluorescence.

\section{Growth variables}

Plant height was measured from the root-stem transition region at soil level (crown) to the tip of the stem using a graded ruler. The stem diameter was measured at the crown with a digital pachymeter. The number of leaves was obtained by counting. The roots, stems and leaves were separated and dried in an oven at 72 oC until constant dry weight and then weighed. The dry matter data were used to calculate the biomass, root mass ratio, stem mass ratio and leaf mass ratio.

\section{Photosynthetic pigments}

To determine the total chlorophyll and carotenoid concentrations, $0.6 \mathrm{~mm}$ diameter leaf discs were removed from completely opened leaves and placed in test tubes containing dimethyl sulfoxide (DMSO). Then extraction was carried out in a water bath at $65{ }^{\circ} \mathrm{C}$ for one hour. Aliquots were removed for spectrophotometric reading at 480, 649 and $665 \mathrm{~nm}$. The contents of chlorophyll a $(\mathrm{Cl} a)$, chlorophyll
$\mathrm{b}(\mathrm{Cl} b)$ and total carotenoids (Car) were then determined according to the equation proposed by Wellburn (1994).

\section{Relative Water Content}

To obtain the relative water content, ten $12 \mathrm{~mm}$ leaf discs were removed, weighed and placed for four hours to saturate in petri dishes with distilled water. The discs were again weighed and placed to dry at $70{ }^{\circ} \mathrm{C}$ for $72 \mathrm{~h}$ to obtain the dry matter weight.

\section{Transpiration}

The total daily transpiration of the plant was determined from the difference in the mass of the pots. The set of pots with plants were placed in individual plastic bags, a rubber band was tied around the stem of the plant, leaving the canopy (leaves and stem) exposed. The pots were weighed at 12 o'clock (mass 1 ) and again 24 hours later (mass 2 ). The total transpiration was estimated based on the difference between mass 1 and mass 2 (Dos Anjos et al., 2017).

\section{Fluorescence}

Chlorophyll $a$ fluorescence was analyzed using a portable fluorometer JUNIOR-PAM (Walz, Germany) at 4 a.m. with 0.3 second light saturation pulse emission under $0.6 \mathrm{KHz}$ frequency, at 30 days after implementing the water regimes. The fluorescence data were computed using the software, WinControl-3.

\section{Statistical Procedures}

The variables were submitted regression analysis using the software SigmaPlot10 (Sysstat, 2006). Multivariate analysis was carried out by multiple regression using the forward stepwise model (Sokal and Rolf, 1995) in the STATISTICA software (Statsoft, 2007).

\section{Conclusions}

The J. curcas plants presented an isohydric system of stomatal control and maintained the water status under water shortage. Under excess water, alteration in the root system and relative water content preceded reduction in stomatal conductance. The initial grow of J. curcas was shown to be sensitive to water deficit and but not very vulnerable to excess water.

\section{References}

Abobatta W (2019) Jatropha curcas: an overview. J Adv Agric. 10: 1650-1656.

Almeida LM, Matos FS, Bailão EFLC, Gonçalves PJ (2019) Jatropha curcas L. Latex Production, Characterization, and Biotechnological Applications. In: Mulpuri S, Carels N, Bahadur B (ed.). Jatropha, Challenges for a New Energy Crop: a Sustainable Multipurpose Crop. Springer, 3: 439459.

Alvares CA, Stape JL, Sentelhas PC, Gonçalves JLM, Sparovek G (2013) Köppen's climate classification map for Brazil. Meteorol Z. 22: 711-728.

Cunha RLM, Galvão JR, Alves RM, Gomes VA, Oliveira FC, Ferreira IVL (2018) Ecofisiologia de progênie de cupuaçuzeiro submetida a déficit hídrico e reidratação. Rev Bras Agric Irrig. 12: 2500-2509.

Dias LAS, Leme LP, Laviola BG, Pallini A, Pereira OL, Carvalho M, Manfio CE, Santos AS, Sousa LCA, Oliveira TS, Dias DCFS (2007) Cultivo de pinhão-manso (Jatropha curcas L.) para 
produção de óleo combustível, 1rd edn. Viçosa: LAS Dias. 40.

Drumond MA, Oliveira AR, Simões WL, Junqueira NTV, Anjos JB, Laviola BG (2016) Produção e distribuição da biomassa de pinhão manso no semiárido brasileiro. Cerne. 22: 3242.

Durães FOM, Laviola BG, Mike LU (2009) Pinhão Manso: oleaginosa potencial para biodiesel I Congresso Brasileiro de Pesquisa do Pinhão Manso - CBPPM. Edição Especial Embrapa Agroenergia 2009.

Gomes CA, Assis LP, Alves DP, Reis MR (2018) Aplicação de ácido salićlico como atenuador dos efeitos do déficit hídrico no milho. JCEC. 4: 01-05.

Kamel DA, Farag HA, Amin NK, Zatout AA, Ali RM (2018) Smart utilization of Jatropha (Jatropha curcas Linnaeus) seeds for biodiesel production: Optimization and mechanism. Ind Crop Prod. 111: 407-413.

Matos FS, Carvalho DDC, Souza AC, Neves TG, Ribeiro RP, Cruvinel CKL, Rosa VR, Santos PGD (2014a) Viabilidade agronômica do consórcio entre pinhão manso e soja. Agrarian. 7: 226-232.

Matos FS, Ciappina AL, Rocha EC, Almeida LM (2018) Fatores que influenciam na produção de látex de Jatropha curcas L. Bragantia. 77: 74-82.

Matos FS, Torres Junior HD, Rosa VR, Santos PGF, Borges LFO, Ribeiro RP, Neves TG, Cruvinel CKL (2014b) Estratégia morfofisiológica de tolerância ao déficit hídrico de mudas de pinhão manso. Magistra. 26: 19-27.

Padilha NS, Silva CJ, Pereira SB, Silva JAN, Heid DM, Bottega SP, Scalon SPQ (2016) Crescimento inicial do pinhãomanso submetido a diferentes regimes hídricos em latossolo vermelho distrófico. Ciên Fl. 26: 513-521.
Pompelli MF, Barata-Luís RM, Vitorino HS, Gonçalves ER, Rolim EV, Santos MG, Almeida-Cortez JS, Endres L (2010) Photosynthesis photoprotection and antioxidant activity of purging nut under drought deficit and recovery. Biom Bioenerg. 34: 1207-1215.

Sá FVS, Mesquita EF, Souza FM, Mesquita SO, Paiva EP, Silva AM (2017) Depleção de água e composição do substrato na produção de mudas de melancia. Rev Bras Agric Irrig. 11: 1398-1406.

Silva SS, Pordeus RV, Lima RLS, Azevedo CAV, Silva AAR, Neto JD (2018) Superfície de Resposta e Adubação Orgânica e Fosfatada Para a Cultura do Pinhão-Manso. Rev Verde Agroec Desenvolv Sustent. 13: 289-301.

Sokal RR, Rolf FJ Biometry Third edition. WH Freeman, New York, 1995.

Souza VHAD, Santos LT, Campos AF, Carolino J (2016) Um Panorama do Biodiesel no Brasil e no Mundo: Esforços para a Ampliação do Setor e Desafios. Rev Augustus. 21: 117-130.

Statsoft Inc. Statistica (data analysis software system). version 7. 2007.

Sysstat Software, INC - SSI. SigmaPlot for Windows. version 10. 2006.

Taiz L, Zeiger E (2017) Fisiologia vegetal. 6rd edn. Porto Alegre: Artmed. 858.

Tavares ACS, Duarte SN, Dias NS, De Miranda JH, Arraes FDD, Sousa Neto ON, Fernandes CS (2018) Efeito da inundação do solo nos índices fisiológicos da cana-de-açúcar. Rev Ciênc Agrar. 41: 229-235.

Wellburn AR (1994) The spectral determination of chlorophylls $a$ and $b$, as well as total carotenoids, using various solvents with spectrophotometers of different resolution. J Plant Physiol. 144: 307-313. 